\title{
EXHUMING DEAD PERSONS: Forensic Science and the Making of Post-fascist Publics in Spain
}

\author{
JONAH S. RUBIN \\ Knox College \\ (DD https:/ / orcid.org/0000-0002-8694-4496
}

In March 2011, Spain's Association for the Recovery of Historical Memory (Asociación para la Recuperación de la Memoria Histórica, or ARMH) and the Aranzadi Society of Sciences inaugurated the traveling exhibit Exhuming Graves, Recovering Dignities at the Carlos III University of Madrid. A collaborative project between the two most prolific organizations associated with Spain's "historical memory movement," the installation conveyed how civil society organizations locate and exhume the more than 150,000 civilians killed during Spain's civil war (1936-1939) and the ensuing dictatorship of Francisco Franco (1939-1975), civilians who remain buried in a series of unmarked mass graves throughout the country. Around the circumference of the building's lobby, a series of stations explained the stages of an ideal typical exhumation, starting with relatives' oral testimony, moving to archival investigations, prospection, digging, laboratory analysis, and culminating in a public reburial service. At the center of the lobby, marked off by low-hanging ropes, lay the centerpiece: a life-sized photographic reproduction of a fully excavated mass grave. If most madrileños would never come face to skull with a mass grave, then the exhibit would bring the experience of witnessing an exhumation, or at least a simulacrum of it, to them (see Figure $1^{1}$ ). 
Dr. Francisco Etxeberria, Spain's most prominent forensic scientist and the president of Aranzadi's forensic anthropology department, provided the opening address: "I believe that the work of historical memory that we are doing in Spain . . . works to build democracy day by day. We are building democracy and reinforcing values, ... one of which is truth, the other is justice, and the third part is reparation." He quickly added, "just in case there are any historians in this room," that "historical memory does not claim to reconstruct past history in a faithful manner. That is the responsibility of historians. What historical memory speaks to is the present."

"In the end," he concluded, "it all comes back to persons. You cannot deal with all of this with the idea that a skeleton is an object. A skeleton is a person with an identity, with feelings. And this is something that you cannot lose sight of when you are in this phase of recovering remains."

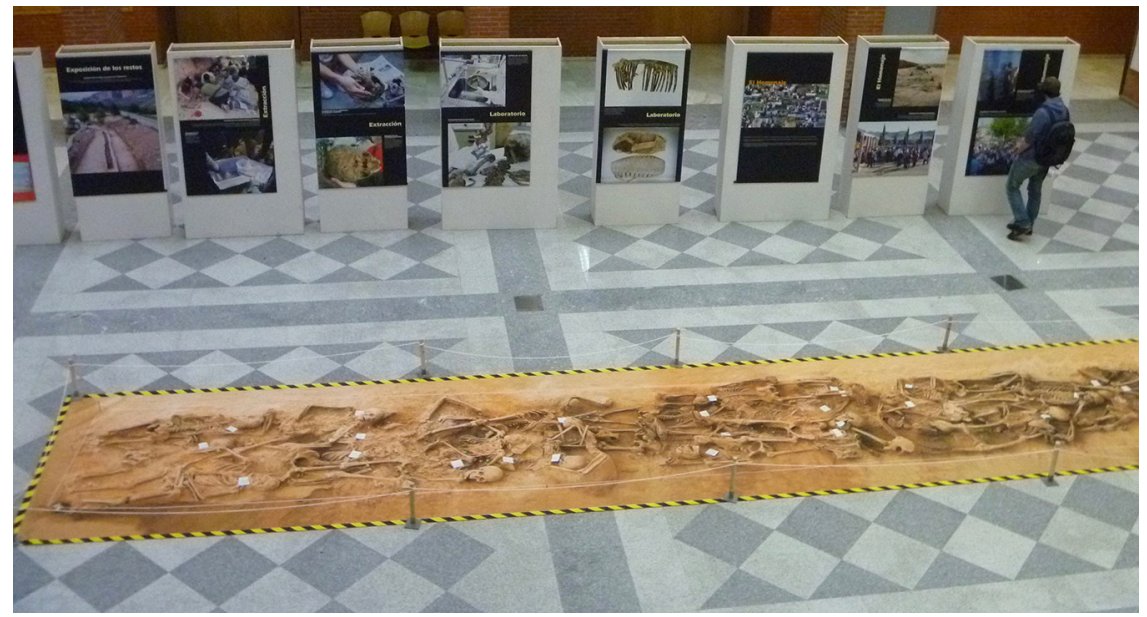

Figure 1. Exhuming Graves, Recovering Dignities traveling exhibit at the Carlos III University of Madrid. Photo by Jonah S. Rubin, March 2011. See Note 1 for a discussion of the ethics of displaying photos of human remains.

In invoking truth, justice, and reparations as the fundamental principles of historical memory, Etxeberria situates Spanish forensic science firmly within the project of post-conflict transitional justice. For transitional justice advocates, late twentieth-century exhumations heralded a new "forensic turn" in human rights (Gessat-Anstett and Dreyfus 2015; Dziuban 2017). Whereas previously historians and lawyers alike had to rely on the faulty memories of often-traumatized witnesses or the biased documents of perpetrator states, forensic science promised to open a new and putatively objective archive by transcribing the "history of their 
life and death recorded in their bones" (Steadman 2003, x). In the aftermath of mass violence, forensics promised a common, factual foundation for reforging a fractured polity.

Ethnographers have rightly expressed skepticism at the positivism and historicism that undergird this triumphalist human rights account. Forensic methodologies, they point out, are designed first and foremost to produce evidence for legal forums (Keenan and Weizman 2012, 28). As such, they respond to the epistemological demands of particular juridical systems, whose standards for truth may diverge dramatically from those of scientists or historians (Jasanoff 1997, 9). Because of their fundamental entanglement with the law, exhumations, in they eyes of anthropologists, have tended to provide not so much incontrovertible historical proof as "neither fully neutral nor purely objective" information that "enters a landscape of contested narratives," supplying "political and moral capital" to different political programs (Rosenblatt 2015, 65). ${ }^{2}$

For Etxeberria, though, exhuming the dead is not about narrating the past at all, a task he leaves to historians. Instead, it is about securing Spain's democratic future, a project that remains incomplete, four decades after the fall of the dictatorship. For the historical memory movement, Spain cannot be a true democracy until it exhumes the unmarked mass graves in which Franco's victims remain. This is so not only because of the ways this ongoing war crime violates the rights of kin to know the fate of their loved ones but also because it violates the dignity of dead persons.

The present essay examines how memory activists use forensic science to challenge the Spanish state's relationship to Franco's victims and, in so doing, its claims to democratic legitimacy. Departing from popular and scholarly depictions, I show that, in post-Franco Spain, the impact of exhumations has little to with their ability to extract historical information directly from the bones of victims. Instead, I argue that exhumations transform the disappeared into dead persons, thereby reincorporating them as integral participants in a democratic public sphere. For memory activists, the project of securing Spain's democratic future depends on recognizing the long-excluded victims of fascist violence as persons.

In examining how exhumations teach the living to recognize the personhood of the exhumed, I aim to reconsider the place of the dead in democratic publics, particularly in the aftermath of state violence. Philosophers have described liberalism as operating on a "dead-are-gone assumption," whereby the deceased can no longer directly affect or be affected by the actions of the polity (Mulgan 1999). Careful ethnographic attention to Spanish exhumations, however, suggests that, 
under certain conditions, the deceased may play a greater role in shaping political processes than generally acknowledged. This results less from the ontological status of the exhumed than from their ability to successfully lay claim to one of the foundational juridical fictions of liberal politics: personhood.

Although colloquially used as a synonym for human beings, in both Anglo and Hispanic traditions, liberal personhood is at base a legal status, denoting those entities capable of participating in public life (Andrews 1911; Cabanellas 1998). It is for this reason that the category can be both more and less expansive than humanity: Corporations in the United States, the ecosystem in Bolivia, and chimpanzees in Spain are all recognized within their respective jurisdictions as "non-human persons," or entities whose interests must be accounted for in the course of public deliberation (Kirsch 2014; Schneider 2015). At the same time, the legal architecture for excluding women and minorities from political participation has often relied on denials of their personhood (Pateman 1988; Patterson 2018).

The issue of the dead's personhood proves especially salient in the context of forced disappearances. ${ }^{3}$ In contrast to a murder or a kidnapping, the violence of forced disappearance manifests not only on the victim's body but also through severing their social and political ties. Forced disappearances transmute public acts of state violence into "intensely private and personal" experiences (Robben 2000, 70). Classified as foreign enemies, rather than rights-bearing citizens, the dead did not have the right to a proper burial and their kin often had great difficulty claiming widow or orphan benefits (Preston 2012, 588). Particularly in the early years of the dictatorship, public recognition of their bond with the disappeared could subject surviving kin to harassment by neighbors and local officials (Ruiz 2005). Barred from public life, the dead could exist only in cries and whispers between close kin and confidants (Ferrándiz 2008).

While Spain's transition to democracy entailed radical transformations in the state's relationship with its living citizens, as I discuss in the next section, the political status of Franco's victims remained largely unchanged. This results in part from the unequal knowledge politics of forced disappearance. For surviving kin, the terror of this crime manifests in the gap between the general knowledge that the state has kidnapped a loved one and the ongoing silence about the specific fate suffered by the victim. This inability to establish public knowledge of disappeared kin while remaining vulnerable to state violence makes such crimes inadmissible in public discourse. Because forced disappearances are defined through a state-sponsored indeterminacy about the fate of the victim, Spanish exhumations aim not only to generate information about the disappeared but also rekindle the 
social and political relations severed by the dictatorship and denied by successive post-Franco governments.

Attending to the personhood of the exhumed requires a reconsideration of how the dead interact with the democratic public sphere. Traditionally, liberal theorists conceive of publics as a kind of "virtual space" in which individuals may "transcend the given realities of their bodies and their status" to debate the future of their community (Warner 2005, 382). From this perspective, it is hard to see what the inclusion of the dead in the public sphere might add, since their private status as the victims of fascist violence should, ideally, fade before the rational arguments they might make before a public audience.

In this essay, I take inspiration from the alternative understanding of publics developed by Hannah Arendt (1998). For Arendt, the democratic public is characterized not by the erasure of individual particularities but rather through the recognition that all persons speak from a particular subject position: "Only where things can be seen by many in a variety of aspects without changing their identity, so that those gathered around them know they see sameness in utter diversity, can the worldly reality truly and reliably appear" (Arendt 1998, 57). On this account, the proliferation of perspectives constitutes a necessary precondition for well-functioning public debate, allowing subjects to be confident in their judgments of what is and what could be. Recognizing the dignity of dead persons, then, fundamentally concerns which perspectives might be included or excluded from post-dictatorship public debate (Zigon 2018, 210). In post-Franco Spain, exhumations are as much an aesthetic as a scientific practice, one that denotes the boundaries of inclusion and exclusion that define the public sphere (see Rancière 2010).

This understanding of the public sphere calls particular attention to the temporal dimension of personhood. As the Spanish philosopher Julián Marías (1996, 15) argues, claims of personhood are inherently "oriented towards the future." That is, if personhood denotes those perspectives with which we might partner to assess and act on the present, then it is synonymous with those entities with whom we might partner to build a more just society. Although objects might be used in working toward a better future, Marías notes, persons can collaborate with each other to achieve the kinds of collective action that cannot be reduced to any of its members.

Franco's campaigns of forced disappearances, then, constituted an attempt to circumscribe the possible futures that might emerge from the public. In forcibly disappearing politicians, union activists, schoolteachers, and other public figures 
associated with the republic and banning any attempts to publicly reckon with their deaths, the dictatorship also sought to restrict the perspectives that could comprise the public sphere. If publics are a kind of performative, world-making poetics (Warner 2005, 114), then Franco's campaigns of forced disappearances attempted to delimit Spain's possible political futures. Moreover, insofar as the foundational settlements of post-Franco democracy continued to exclude the disappeared from the "space of appearance," they also continue to impoverish Spanish political life (Arendt 1998, 200). Despite significant reforms, the post-Franco state's ongoing failure to recognize its deceased citizens as persons represents a continuation of the antidemocratic policies the dictatorship imposed to constrain the public sphere.

In the hands of Spanish memory activists, international forensic protocols accomplish more than just the productions of historical evidence of past war crimes. Memory activists creatively deploy forensic procedures to challenge a political system built on the exclusion of disappeared persons' perspectives from public debate and revive alternative political futures. Before examining the transformative power of exhumations, though, we must first focus on the particularities of the Spanish forensic context.

\section{FORENSIC HISTORY AND DEMOCRATIC TRANSITIONS}

Early in my field research, I visited the laboratory of the ARMH in the northwestern city of Ponferrada. As I entered what some activists call "the laboratory of hope and dignity," a specialist stood at a table, gluing together bone fragments, in an attempt to reconstruct the crania of two recently unearthed victims. Across the room, a lab worker combed through some documents. Although the location of most successful exhumations is provided by relatives of the missing, these records remain critical for building a historical profile of the disappeared. In the middle, an archaeologist busied himself compiling survivor testimonies, field journals, physical anthropological analyses, photographs, and more into a report on the team's latest successful effort to identify the disappeared.

The scene was instantly recognizable to anyone who has followed similar efforts to recover the missing after mass atrocities. And for good reason: From the start, Spanish exhumations were explicitly modeled after the sorts of high-profile exhumations that accompanied Latin America's transitions from dictatorship to democracy (Silva and Macías 2005).

But although the techniques and technologies of forensic science crossed the Atlantic with ease, the context of their deployment differs markedly (Rubin 2014). 
The Latin American exhumations that inspired Spanish activists occurred as part of state-led transitional justice programs. As such, they were designed primarily to generate legal evidence for a war crimes tribunal, truth commission, or other juridical process. By contradistinction, Spanish forced disappearances fall into something of a legal black hole: Spain's 1977 Amnesty Law prevents local justices from investigating the dictatorship's crimes (Aguilar 2002). The European Court of Human Rights has ruled that the statute of limitations for these cases has expired (Márquez and Melón 2012). And, as most disappearances occurred prior to the foundation of the United Nations in 1945, the Committee on Involuntary and Enforced Disappearances has determined that they fall outside its mandate, even if they otherwise meet the legal definition of forced disappearance (Greiff 2014).

As my tour of the laboratory concluded, I sat down with Santiago Macias, then vice president of the ARMH and laboratory manager to conduct an interview. Given the lack of legal recourse, I asked him, why were memory activists so committed to following strict technocratic procedures for generating forensic evidence from ossified human remains?

Macias conceded that, for fulfilling the rights of kin, the technical procedures were relatively unimportant. After all, most of the time, it was relatives who pointed out not only the location of mass graves but also provided the names of those buried therein. At best, forensic analysis could confirm what they already knew. However, he continued, "in a country like Spain, our work must be incontestable. Otherwise, tomorrow someone could come and claim that these were victims of [the other side]." He quickly added that this was not to criticize an earlier generation of Spaniards who, in the immediate aftermath of Franco's death, set out "practically in secret" to recover the remains of their loved ones (see Hristova 2007). However, "our work," he insisted, "needed to be an act of justice" that "speaks to the world" and helps "normalize democracy."

At first glance, Macias seems to be advancing a rather straightforward argument about the great powers of forensic science to reveal historical truths about past violence. Since the late 1980s, advancements in physical anthropological and archaeological technologies have made scientific expertise central to the prosecution of both war crimes and more mundane legal processes, leading some to proclaim the current age an "era of forensics" (Keenan and Weizman 2012; see also Comaroff and Comaroff 2016). For human rights advocates, these new techniques promise to act "as a vital provider of physical and documentary evidence in trials of perpetrators of mass atrocity that has 'unparalleled benefits' that 'don't lie"” (Pearlman 2008, 5). 
But why should forensic evidence be especially needed in a country like Spain, where the possibility of legal justice has been foreclosed?

In the state-led exhumations that inspired Spanish activists, the production of forensic history is seen as a lynchpin of post-conflict peacebuilding. According to transitional justice theorists, "abusive regimes thrive in secrecy, seeking to hide their wrongdoings within and outside the county. Often, even the perpetrators of human rights abuses are ignorant of all that their peers are doing and the general public is usually not fully aware of what is being done in their name" (Humphrey 2012, 259-60). For transitional justice theorists, ignorance, rather than ideology, is the fons et origo of mass violence.

Therefore, in the aftermath of dictatorships, transitional justice practitioners profess faith in the therapeutic powers of accurate historical narration. Confronted with long-hidden truths, former warring parties will be convinced "to give up their coercive politics, and to adhere to the rules required by a democratic order" (Sánchez Gómez 2016). At a moment when civic unity has been ripped asunder, transitional justice practitioners invoke forensic history making to ground renewed liberal norms.

Spanish democracy, however, was founded on very different terms. Conducted over a decade prior to the rise of the transitional justice paradigm, Spain's democratic transition avoided any public reckoning with past crimes. Following then-contemporary ideas of best practices, in the wake of Franco's death, Spanish politicians undertook a Pact of Oblivion (Pacto del Olvido), a tacit agreement among the political elite not to legislate, litigate, or publicly discuss their recent history (Encarnación 2014). By setting aside a still divisive past, Spain's political class hoped that, together, they might build a common future.

The Pact of Oblivion never entailed an outright ban on engagements with the past. In fact, a flurry of new academic research accompanied the end of the dictatorship, written with the aim of countering Francoist propaganda (Boyd 2008, 137). It was only when such commemorations erupted into the broader public sphere, threatening the renewed democracy's "regimes of visibility," that they became subject to censorship (Leivas and Kerangat 2018). Thus, even as critical historical studies proliferated, conference posters making visual references to the flag of the Second Republic were "unofficially, but effectively banned" (Preston 2012, 8-9). And although the new democracy now permitted families to privately rebury their republican kin, the government censored public screenings of the film, Rocío, removing a scene in which the names of the disappeared are read aloud (Espinosa-Maestre 2013, 8-9). 
Whatever its political theoretical ambitions, in practice, the Pact of Oblivion meant that victims' kin experienced the transition as a continuation of the dictatorship's violence. Even as Spain undertook ambitious constitutional reforms, the violence of the dictatorship remained a public secret, known to all in its broad strokes and yet barred as the condition of possibility for post-Franco public life (Taussig 1999). Yet the hasty attempts of politicians to impose public finality on the stories of the disappeared left few options for families seeking to learn the specific circumstances of their loved ones' deaths and to provide them with last rites.

Despite lacking the kind of public reckoning with its past that transitional justice sees as essential, by most international measures, Spain remains a stable democracy. Moreover, although the civil war and the Franco dictatorship remain controversial topics in the public sphere, opinion polls indicate that this is not due to an ignorance of historical facts. According to a 2008 survey, only 0.2 percent of Spaniards deny the existence of mass graves, while the vast majority (88.2 percent) agree that Franco violated basic human rights (CIS 2008; 4.3 percent disagree).

Whatever faults Spanish memory activists see in their compatriots' relation to the past, it is not the kind of widespread ignorance that transitional justice theorists would lead us to expect. To understand why Spanish activists so highly value forensic science, even in the absence of legal backing, we will need to more closely examine how exhumations challenge the foundational settlements of the post-Franco public sphere.

\section{(HOW) DOES SCIENCE PROVE HISTORY?}

Spirits were low in La Toba de Guadalajara as the Forum for Memory neared the end of its third day searching for the grave of Severiano Clemente González, a baker and sympathizer of the leftist Popular Front, killed by fascist militias on November 17, 1936. A large backhoe continued digging trenches across the roughly square kilometer field, hoping to encounter some sign of the informal burial. But so far, only a few hunting shells and some animal bones had emerged. Several activists began to wonder aloud when to give up the search.

As the day wore on, more people came by the ongoing prospection to corroborate the original testimony of González's children and confirm that the victim had, in fact, been buried in this location. But the terrain had undergone significant changes in the ensuing seventy-five years, erasing the once familiar landmarks by which people navigated the area.

A social psychologist tried to prepare the relatives for an increasingly likely disappointing scenario: "Whether we find it or not, we know the facts. What is 
important is the history, and that much we know." The sentiment seemed to reassure one of González's sons, who replied that, thanks to media reporting on our efforts, "in the village, they know it all."

I sat down with the social psychologist and the lead social anthropologist to conduct an interview with two of González's sons. Regardless of the search's outcome, the organization wished to record and archive the testimonies of those who knew the victim (Renshaw 2011; Ferrándiz 2014). Just as I hit the button on my audio recorder, though, an excited shout came from across the field: "We found bones!”

Cheers rang out as people enthusiastically ran over to the backhoe that, at long last, had encountered human remains. Tears welled up in the eyes of González's children and grandson as they gave emotional hugs of gratitude to all around.

As the initial excitement passed and the forensic team got back to work, one of Gonzalez's sons turned to the social psychologist and commented, "What a joy!" Then, recognizing the awkwardness of expressing happiness at finding the skeletal remains of a father who had been violently murdered for his political beliefs, he added: "Well, it's a joy, but it's not a joy." The social psychologist reassured him: "Yes, it's a joy. Because it confirms the history. . . . Now we need science to confirm it." A few months later, science did just that as physical anthropological and genetic analysis confirmed the identity and cause of death of Severiano Clemente González.

As with Macias's comments in the ARMH laboratory, the Forum for Memory's exhumation of González seems like a straightforward story about the great potentials of forensic technologies to definitively confirm memories of past violence. To a certain extent, the laudatory discourse of human rights scholars is reflected in the technical practices of Spanish forensic teams. Historical memory associations speak of forming "hypotheses" about the location of mass graves based on oral testimony. For both forensic specialists and lay activists, exhumations function to confirm these suppositions.

But, as the difficult path to discovering the González burial site indicates, the hypotheses tested by forensic scientists differ quite markedly from those that may be evaluated in a laboratory. Even at the moment when hopes of locating González's grave were fading fast, the veracity of his relatives' testimony was never in doubt. As the social psychologist assured him, "Whether we find [the grave] or not, we know the facts." The history of this war crime, she emphasized, was already known prior to the discovery of any human remains. Unlike the propositions tested in the laboratory, the ones offered by victims can never be falsified. 
This became evident at dinner one night, after over a week in which the ARMH had attempted, unsuccessfully, to locate a burial site. "What do we do when we don't find a grave?” asked one volunteer. "Because I once read [in a newspaper after another unsuccessful prospection] that the ARMH failed." The volunteer expressed outrage at the notion that the failure was that of the NGO, rather than of the state, which refused to undertake its legal and moral obligations to locate the disappeared. ${ }^{4}$ The vice president of the association replied: "We do not say that the search failed. . . Instead, we say that we have suspended the search." "Because it does not end," another activist finished the thought. A testimony may lack the precision necessary to locate human remains, but its truth value is never in question.

Even when these "hypotheses" can be proven, though, the question of what, exactly, has been established remains somewhat elusive. The analysis of González's remains certainly produced significant quantities of new data: It definitively established the location of his interment, the precise manner and method of his death, the caliber of the bullet used, and much more. In graves that contain multiple bodies, forensic science can often identify groups of persons executed together, the order in which they were killed, and sometimes even significant details about their final moments.

This information is highly valued by those who maintain an affective link to the deceased, be they related by kinship or ideology. At one exhumation, a relative recalled how, as a child, he would come with his mother every Day of the Dead to leave flowers at the entrance of the farm where the grave had been discovered. A friend marveled at the precision of his memory, noting that his testimony had led to the expedited discovery of the victims. The relative, however, took offense at the suggestion that a proximate location was good enough: "No! It was not exact!" he insisted, noting that the actual grave had been discovered a good five meters from where they would leave flowers.

And yet, forensic analysis alone cannot produce the sort of information that families and activists value most. While, under ideal conditions, an exhumation can reveal who was murdered, where, and how, it cannot reveal why a person was killed. Details like that of a man who was forced to bury five bodies at gunpoint, a schoolteacher who was murdered for reading socialist newspapers, or how González was killed for giving his leftover bread to the poor-that is, the narratives that comprise both the local and the national histories of Franco's repression - can only be derived from the testimonies of those who remember the dead. Here, forensic data acts as a Derridean supplement, supplying the facticity that 
oral accounts on their own lack, even as, in most cases, it adds little substantive information to the testimonies of kin (Derrida 1998).

Forensic scientists are well aware of this reality. Even when exhumations go as planned, the claims made in their reports remain rather constrained: "The evidence found, as well as the analysis of the grave as a whole, allow an interpretation of the grave that is consistent with the testimonies of the relatives before and during the exhumation" (Crespo Prieto 2008; emphasis added). Although forensic exhumations produce vast quantities of new information, they cannot, strictly speaking, confirm the stories families tell about their loved ones. It can only yield evidence that "allows an interpretation of the grave" along the lines of what they have said. This is both a straightforward commentary on the plausibility of oral testimony as well as an acknowledgment of the ways internationally recognized forensic protocols open up the space for the kinds of public testimonies barred by the tacit Pact of Oblivion.

What emerges from this ethnographic description of forensic science in practice differs substantially from the popular image of scientists using "archaeological techniques to test witness testimony" (Schmitt 2001, 280). Far from extracting truths about past crimes directly from the bones of victims, history, as the Spanish experience shows, precedes, rather than follows from, the forensic exhumation. This was certainly the case in La Toba, where, as the social psychologist pointed out prior to the discovery of the remains: "Whether we find it or not, we know the facts. What is important is the history, and that much we know."

In contrast to its popular and scholarly representation, the goal of the exhumation is not to overrule less reliable ways of knowing the past. Instead, at its most successful, forensic science proclaims its own inadequacy, demanding a public accounting for facts about the dead it has produced, but is not capable of fully explaining on its own. As the forensic report indicates, in order to publicly account for how the facts that emerge from laboratory analysis came to be, one must return to the testimony of the victims' kin. Far from supplanting witness testimony, forensic science proclaims its necessity.

Rather than producing a single, definitive account of the disappeared, forensic science aims to multiply the things that may be said about them. In the course of a single exhumation, the dead body is subjected to (and subjectified by) a wide variety of technical fields - including archaeology, physical anthropology, medical pathology, ethnography, history, social psychology, and the law - each with its own methodologies and standards of proof (Crossland 2013). 
In the state-sponsored exhumations that inspired Spanish activists, the inevitable gaps between these varied performances of the dead are not especially problematic. Conducted in the context of official programs of transitional justice, truth commissions and war crimes tribunals provide a ritual vehicle for uniting varied scientific and sovereign performances into an authoritative account of past violence (Moon 2009, 56-58). Like all judicial proclamations, these must exceed a strict reading of facts (Derrida 1992; Keenan and Weizman 2012, 24). Like a pointillist painting coming into focus as one backs away from a canvas, the judicial declaration stabilizes the varied performances into a singular, authoritative, public account of state violence.

In Spain, however, no such possibility exists for attaining any official legal pronouncement. Like the transitional justice exhumations that served as their model, Spanish forensic reports demand a public accounting for facts about the dead that scientists produce yet cannot fully explain. Yet unlike the interventions that inspired Spanish memory activists, the state refuses to provide any such public accounting. Therefore, memory activists seek alternative means for transforming the post-dictatorship public sphere.

\section{RECOGNIZING PERSONS, JUST LIKE YOU AND ME}

Absent the authoritative proclamations of the state, Spanish forensic teams must go beyond international protocols for interacting with dead bodies, and develop procedures for managing the many living persons who gather to watch exhumations. Memory activists encourage these visits, establishing viewing galleries and discussion spaces in the immediate environs of excavations (see Figure 2).

The sight of a mass grave can be confusing to the untrained eye. After more than seventy years of decay, even the best-preserved human remains no longer resemble the living in any straightforward way. Recognition becomes even more difficult when bones are comingled or overlapping, buried in acidic or humid soil that accelerate decomposition, or if subsequent building at the surface level has affected the substrata. Particularly in graves where crania are no longer easily discernible, people's first reaction on witnessing a mass grave is not sympathy, outrage, or horror: it is incomprehension and despair.

In response, the memory movement invests much time and effort explaining the forensic tableau to the uninitiated. At least once a day, the team leads "mobile seminars," explaining an opaque burial scene to those who do not know (Bevernage and Colaert 2014, 5; see Figure 3). To understand the place of forensic 


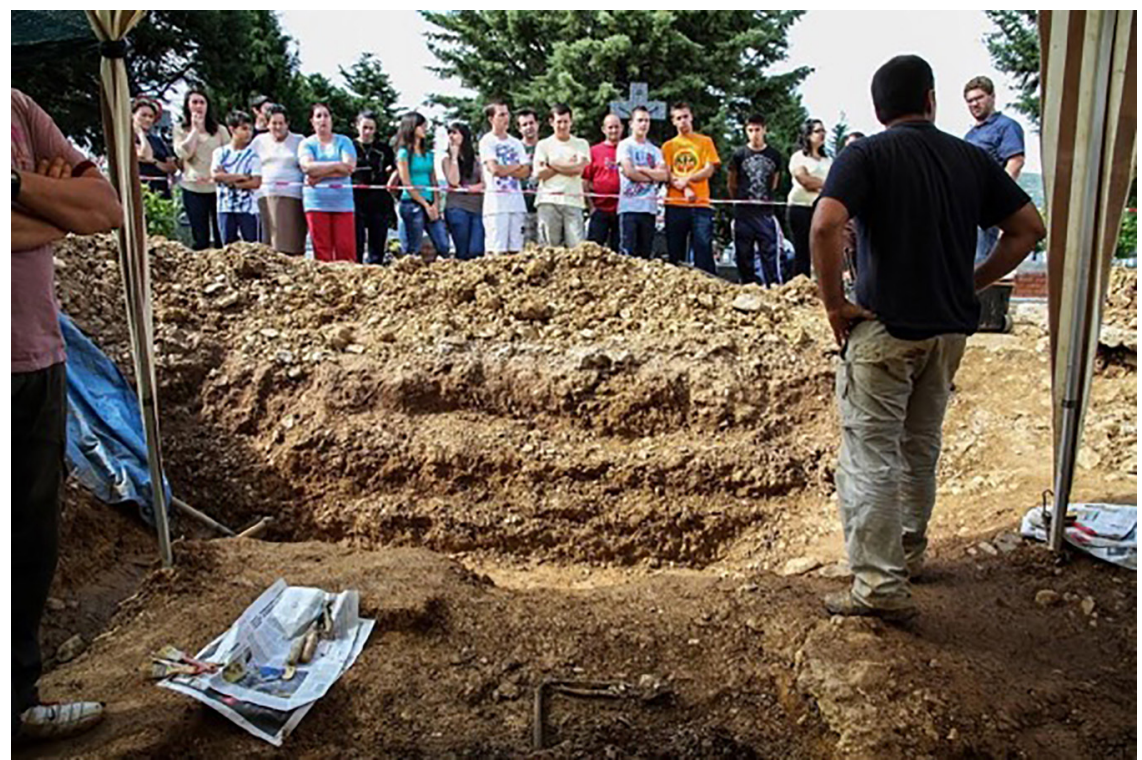

Figure 2. Exhumation teams established distinct zones for families and visitors to watch ongoing forensic activities, along with discussion spaces and interviewing areas (not pictured). Photo by Óscar Rodríguez, 2011.

science in these exhumations, it will be helpful to focus on one such explanation. ${ }^{5}$ The lead archaeologist began by welcoming his audience:

I don't know if you've ever seen a mass grave before. This is a mass grave. This is an unknown reality that, unfortunately, attempts have been made to hide it. This is a reality and I say that because we have here five persons that - perhaps now it is difficult for you to see — . . . but we have five persons who were killed in ' 41 and who were brought here, a grave was dug and, just as the remains fell, that's how they were buried, and that's how we are finding them now. ... Once we begin to take them out, we put them all individually — that is, one by one - in a box and transport them to the laboratory to do the forensic anthropological report and identify these persons. I'll explain to you, for example, one of these bodies, so that you can see it. Let's look for example, at [individual] number 3.

In the absence of a formal legal procedure, the archaeologist introduced onlookers to the mass grave by making the authoritative ontological statement that elsewhere might be provided by a judge or truth commissioner, twice affirming, "this is a reality." The archaeologist needed to repeat this, he explained, precisely because 
of the nature of forced disappearance. Like other dictatorships, the Franco regime did not simply kill its victims; it denied their very existence (Gatti 2014). Although Spain's transition to democracy entailed substantial reforms to the ways state institutions governed the living, the Pact of Oblivion proscribed the possibility of any changes to its public management of the dead.

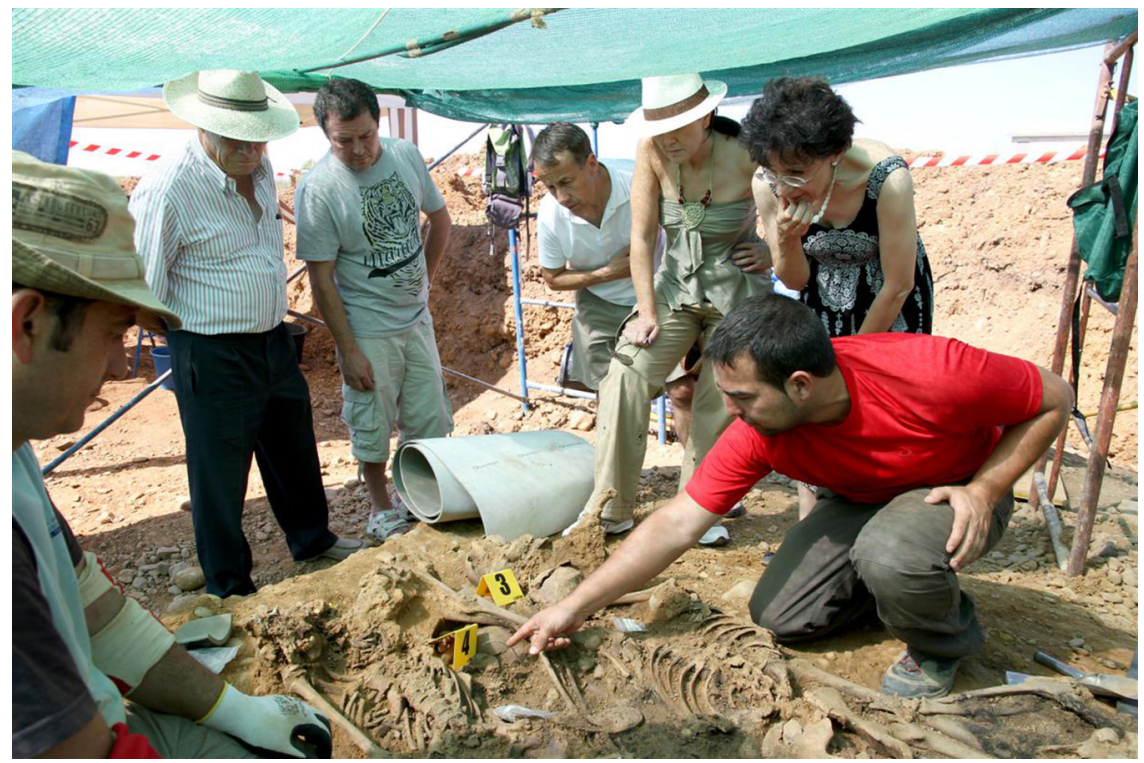

Figure 3. ARMH lead archaeologist René Pacheco points out forensic details to visitors and relatives of the disappeared during a forensic seminar. Photo by Óscar Rodríguez, 2011.

The proof of the victims' reality is not, as transitional justice scholars would have it, extracted from the bones of its victims. As with the Forum for Memory's exhumation at La Toba, here, too, the specialist confidently narrates the grave's history prior to any laboratory analysis. Instead, the proof of the dead's reality is aesthetic. Despite the deteriorated state of the remains, the expert reassures the onlookers, they too will soon learn to see the jumbled bones as human bodies. And in short order, he proceeded to retrain their visual fields, illustrating the number and disposition of each corpse, making sure that each of them became capable of seeing within the jumble of confusing remains a series of individual bodies. Here, the presence of bodies comes into focus by training onlookers to inhabit a basic forensic medical gaze (Araguete 2013, 10).

The archaeologist's lesson on how to properly perceive the mass grave is a staging of what Jacques Rancière (2010, 37) calls dissensus. Against a dictatorship that sought to erase their public existence and a democracy that continues to ne- 
glect the disappeared, the archaeologist "makes visible that which had no reason to be seen" under the existing political order (Rancière 2010, 38). In so doing, he opens up a "gap in the sensible," calling attention to those who have been overlooked, and therefore violently excluded, from the political community (Rancière 2010, 38). Insofar as a well-functioning public sphere depends on a plurality of particular perspectives (Arendt 1998, 57), the archaeologist's highlighting the public exclusion of those who resisted fascism also demonstrates the impoverished nature of post-Franco democracy.

This aesthetic retraining concerns more than just seeing once overlooked objects. For in "transforming this space of "moving along" into a site of historical significance, the archaeologist also opens up "a space for the appearance of a subject" previously neglected in the public sphere (Rancière 2013, 17). As the jumble of bones becomes a series of individuals, onlookers often raise their arms, lower their jaws, or cross their legs, mimetically adopting the positions of the human remains. Mimesis, as Michael Taussig (1993, xiii) notes, is "the faculty to yield into and become the other." In unconsciously adopting the bodily dispositions of the departed, the living come to recognize their own bodies as being fundamentally like those of the dead, save for a few of decades of decay.

As the archaeologist continued, he urged onlookers to extend these feelings of mutuality beyond the corporeal:

I don't know whether you can come to this idea, but it is a person. It is a person just like me, just like you. ... These people are the parents, the siblings, the grandparents of people like us. And they have been waiting for more than seventy years for someone to find their bodies, and with this work we are trying to give these families the opportunity to recover them and to bury them with dignity in a niche, which is all they are asking for.

While describing the forensic identification process above, the expert distanced himself from those in front of him, distinguishing between our ability to see, excavate, and analyze the remains, with their never having seen a mass grave before. This effectively established the distance between the expert, object, and layperson that is the sine qua non of scientific specialization (Rosenblatt 2015, 19). In this excerpt, however, the deictic markers shift. By first asserting his own similarity with the deceased and then with the onlookers, the expert hails his audience to recognize themselves as persons who share in the same bodily substance, kinship networks, and desire for a dignified burial as both himself and the dead. In so 
doing, he transforms the dead from silenced suffering subjects into the kinds of persons capable of publicly articulating desires shared by both the living and the dead (Rancière 2010, 38).

The training that started as a practical means for seeing a confusing forensic tableau here culminates in an ethical project. Yet in contrast to transitional justice theorists and their anthropological critics, in the forensic seminar, recovering the missing is not, in the first instance, about forging the kinds of truthful narratives that can inoculate the public from renewed conflict. Instead, it is about building the kinds of communities capable of recognizing Franco's victims as persons.

The tense the archaeologist adopts is particularly telling: It is not just that the dead were persons whose rights had been violated in the past. Rather, they continue to be persons in the present. Memory activists frequently emphasize this commitment to the ongoing personhood of the dead. For instance, over dinner one night, a volunteer complimented this same archaeologist for the way he adapted his forensic seminar for a particularly young audience: "I really liked your explanation [of the grave] to the children. It almost made me cry. . . . We were all there with one eye on you. And you always referred to them as persons.” This sentiment is not restricted to forensic specialists. At one excavation, an elderly woman remarked that though "I know little about politics," to her, "what is important is this, that they come out [of the grave] and they have dignity. They are persons."

Spanish activists, no less than liberal philosophers, do not always agree on what behavior-beyond the basic, movement-defining commitment to properly burying Franco's victims - recognition of personhood ought to compel. At one exhumation, a documentarian from the Forum for Memory criticized the ARMH's photographic procedures. The latter group favors close-ups of the deceased. As one ARMH photographer explained to me, these detailed shots served to "humanize" the bones, helping wider audiences recognize their similarity with the disappeared. For the Forum for Memory activist, however, such photographs "lacked respect" for the dead. He analogized: On March 11, 2004, during the Al Qaeda terrorist attack, "there were cameras all over Atocha" train station in Madrid. Yet the media refrained from showing close-ups of the dead, he noted, "out of respect to the victims." The same protection from the voyeuristic gaze of the media, he argued, was owed to "the victims of state terrorism" whom we were presently exhuming. Regardless of their differences, though, both the ARMH and the Forum's photographic protocols emerge from a shared concern with the dignity of dead persons. While the ARMH draws on humanitarian visual tropes to build recognition of the deceased, the Forum situates the exhumed within hegemonic media 
ethics for representing victims of violence. ${ }^{6}$ Yet regardless of their different media ethics, both organizations mobilize established media tropes for representing victims of violence to make the long-neglected disappeared publicly recognizable as persons whose perspectives must be reckoned within the course of democratic deliberation.

Like all claims to personhood, those made in the name of the disappeared are inherently bound up with their ability to shape the public sphere. Within liberal political systems, the term person is itself a forensic term, a legal fiction denoting those entities permitted to voice their interests and account for their actions in public (Cabanellas 1998; Locke 1998, 258). Often, the category is deployed to include non-human persons whom the polity wishes to grant legal standing while excluding certain humans as a means of silencing their political voices.

Despite personhood's legal reality, though, liberalism relies on an ideology whereby it "appear[s] normal, natural, and prior to political and economic forces" (Collier, Maurer, and Suarez-Navaz 1995, 5). Liberal thought seeks to naturalize personhood by grounding this foundational concept through a productive conflation of personhood and the human body (Scheper-Hughes and Lock 1987). ${ }^{7}$ At the same time, because liberal politics denies personhood to certain humans, liberal philosophy also limits personhood to those bodies deemed capable of "rational thought," "maturity," or “communication” (MacIntyre 2001, 10).

Memory activists deploy forensic science in the gaps between these legal and philosophical aspects of personhood. First, the forensic expert enfolds the disappeared within the kinds of expert scientific and legal discourses that define liberalism's shared cosmological grounds (Asad 1993, 38-39). Then, the pedagogue leads a mobile seminar in which he teaches visitors how to see the bodies of the dead as fundamentally like their own, establishing the shared corporeal grounds central to liberal ideologies of personhood (Farman 2013). Having established the dead both as subjects of law and as sharing in the natural substrata of personhood, the archaeologist calls on his audience to join the public pushing for the dead to be buried with dignity.

\section{DIGNITY AND DEMOCRATIC POLITICS}

Whether it is the dead or their living kin who have awaited this dignified burial for decades is left ambiguous in the mobile seminar. But Etxeberria's inauguration of the Exhuming Graves, Recovering Dignities exhibit suggests that, at the very least, the memory movement considers exhumations as the fulfillment of ethical duties owed the dead by virtue of their inherent dignity. Hence, as he led a 
guided tour of the exhibit, Etxeberria, seemingly contradicting the exhibit's title, noted that exhumations "are not to recover the dignity [of the dead]; they never lost that." Similarly, at a reburial service, an activist for the Forum for Memory declared that this act was "not to recover the dignity [of the dead]. Those who lost their dignity are those who fought against democracy."

In part, invoking dignity is about reinforcing claims for the dead's personhood. Although rarely defined in legal documents (Schachter 1983, 849), the concept of dignity proves foundational to the possibility of liberal jurisprudence and international human rights law (Rosen 2012). The preamble of the International Covenant on Civil and Political Rights, for instance, declares that the rights enumerated therein "derive from the inherent dignity of the human person."

Within Roman civil law traditions like that of Spain, though, there is even more at stake, as dignity also undergirds the possibility of the polity writ large (Chaskalson 2002). Thus, Article 10.1 of Spain's 1978 Constitution cites the "dignity of the person" as part of the "foundation for social order and social peace." Spanish constitutional scholars frequently describe dignity as the "invisible cement" holding together the possibility of political order, even while bemoaning its definitional ambiguity (Jiménez Campo 2018, 219; see also Pascual Medrano 2015).

For Spanish audiences, then, the accusation that the dignity of the dead has been violated concerns more than the rights of an individual dead person. It also calls into question the legitimacy of the post-Franco political order (see Rubin 2018). As Ana Pereda put it at the ARMH-organized exhumation of her grandfather: "A democracy that leaves its dead forgotten in a grave is not a real democracy." Conversely, as one leader of the Platform against Impunity for Francoism declared at a public assembly in Madrid: "The destruction of memory makes the construction of democracy impossible." A true democracy, the memory movement argues, must properly care for dead persons as well as for the living.

Ultimately, the work of historical memory concerns itself with establishing the conditions of possibility for forming an alternative democratic public. This can be seen in one prominent memory activist's reaction to the June 2014 abdication of King Juan Carlos I, in favor of his son Felipe, now the VI. At the time, many leftists were calling for a popular referendum on whether Spain should remain a monarchy or return to a republican system. Juan Carlos, they pointed out, had only become head of state due to the 1947 succession law, which established him as Franco's legal successor. A referendum therefore offered an important opportunity to rid Spain of the vestiges of the dictatorship and ground political authority 
through democratic means. For some memory activists, however, these calls for a referendum missed the point. On a Facebook post accompanied by a photo of an exhumation, one wrote:

A protest in favor of a referendum has been called for this Saturday. . . But there are persons who have not been taken into account, they cannot attend an assembly because they are dead. They were murdered with impunity by fascists, without the right to complain [reclamar], ${ }^{8}$ which is what impunity means. They are not going to go to the protest, but we should bring them. Photos, photos, photos.

At stake in the protest against the monarchy is not only the political status of the dead, nor even just the reciprocal knowledge gained by recognizing the personhood of the disappeared. For this memory activist, any proper consideration of Spain's political future must account for the rights and desires of those dead persons excluded from participation in the public sphere since their forcible disappearance at the hands of the dictatorship.

The work of historical memory, then, extends beyond the recovery of bones to include attempts to restore these missing perspectives. As Emilio Silva, the president and founder of the ARMH remarked on the 2012 International Day of the Disappeared: "They made them disappear, but they were then transformed into seeds, into the DNA of ideas. ... They uproot you from the present but a root always remains, a seedling that sprouts new dreams that have beautified the world. Today is their day, today and all the others, but it is the day to scream that their fight for justice has not disappeared." Here, a better future can only emerge once the living commit to advocating on behalf of a project for justice that continues to be defined by the dead.

\section{CONCLUSION: Reconsidering the Place of the Dead in a Post- conflict Democracy}

This essay explored how Spanish civil society organizations deploy forensic science to challenge a state that, four decades after the fall of its dictator, refuses to undertake its legal and moral responsibilities to locate the disappeared. Rent from its legal context, forensic science does not generate the kinds of hegemonic historical narratives imagined by both transitional justice scholars and their anthropological critics. Derived from the Latin forensis, originally referring to the Roman forum in which citizens presented arguments before their peers, forensic 
science entails the scientific production of evidence for a juridical institution. In a context in which neither courts nor legislators willingly admit the evidence that emerges from mass graves, Spanish memory activists look to forensic science not as a mode of addressing a public forum but to create it anew.

Spanish exhumations constitute a tailored response to the particular postmortem violence directed against those who died resisting fascism. Both the Franco dictatorship and its ensuing democracy were premised on the exclusion of the disappeared from the public "space of appearance" (Arendt 1998, 57). For Spanish activists, the publics that exhumations generate must be composed of both living and dead persons. Memory activists devote considerable time and attention to training the living to acquire both the aesthetic capacities and the political subjectivities needed to recognize the long-overlooked dead as persons, who share in the same bodily substance, desires, and political projects as the living (Rancière 2010). Once their personhood is recognized, the long-excluded dead can re-enter the public as entities who demand the recognition of their interests and desires.

Yet Spanish memory activists are far from alone in seeking to recruit victims of state violence as matters of public concern. In recent years feminist groups protesting femicide throughout the Hispanic world have adopted the slogan: "Not all of us are here; we are missing the dead.” Similarly, the \#BlackLivesMatter campaign in the United States sought to make visible the long neglected victims of police violence, in part through the circulation of hashtags such as \#IfIDieInPoliceCustody and \#SayTheirNames, that ask readers to imagine themselves in the place of and join together with the voices of the deceased (Bonilla and Rosa 2015). From the self-immolation that sparked the Arab Spring to the \#WeAreAllAyotzinapa (\#TodosSomosAyotzinapa) hashtags popularized in the wake of the disappearance of forty-three teaching college students in Mexico, popular protest movements increasingly organize themselves in coalitions of living and dead persons. ${ }^{9}$

These cases suggest that we need to pay more attention to the ways in which states regulate postmortem personhood. The management of death has long been considered a cornerstone of liberal statecraft. The sovereign monopoly over the legitimate use of force is defined by its right to kill (Weber 1946), while the necropolitical ability to designate certain populations as not worthy of life is central to the its modern biopolitical management (Mbembe 2003). And yet, for all the attention paid to how states facilitate, distribute, and regulate death, the dead themselves have most often been treated as existing beyond the reach of state power (e.g., Foucault 2003, 248). 
To be sure, anthropologists and political theorists have long recognized the importance of commemorating the dead to the formation of collective political identity. And yet, within these accounts the dead remain a medium rather than an object of state power. For instance, Katherine Verdery's (1999, 27-28) seminal study of post-Soviet exhumations convincingly argues that a corpse's materiality and shared bodily form make it a particularly powerful symbol during times of political upheaval. Yet no sooner does Verdery $(1999,29)$ recognize the symbolic potency of the corpse than she argues that, because "they don't talk much . . . [w]ords can be put into their mouths" by the living seeking to recruit the dead to help sacralize political projects. Here, the dead appear as little more than an empty signifier, there to add affective depth to political projects whose content is always formed elsewhere (see also Anderson 1991, 205).

This omission appears especially surprising given the history of the modern state's attempts to manage the dead. The European liberal reforms that created the modern, purportedly universal individual were enacted through both dead and living bodies. Coterminous with the legal and disciplinary reforms that produced individuals out of masses, radical changes in burial practices for the first time guaranteed all citizens an individual interment in a demarcated spot, rather than inclusion in a common grave (Joyce 2003, 90-91). Similarly, colonial officials in Africa and the Americas understood that remaking indigenous populations into docile subjects required controlling not only the bodies of the living but also the dead as they manifested in funerals, cemeteries, and religious rituals (Comaroff and Comaroff 1991, 218; Lomnitz 2005). This history is mirrored in the writings of contemporary liberal philosophers who argue that, regardless of their ability to exercise postmortem agency, the dead continue to have ongoing interests that require protection (Baets 2004; Moon 2017). ${ }^{10}$

My purpose in calling attention to these varied examples is not to claim some inherent political capacity of the dead; just as the government of the living looks different in distinct contexts, so too does the governance of the dead take on a variety of forms. Yet the Spanish memory movement's work building recognition of Franco's victims suggests the possibility for a kind of radical politics based on resisting the state's attempts to manage the dead.

\footnotetext{
ABSTRACT

Four decades after the fall of its dictator, Spain still refuses to undertake its legal and moral responsibilities to locate the disappeared. This essay examines how Spanish activists use forensic exhumations to transform the political status of Franco's
} 
victims. Departing from popular and scholarly depictions of forensic science, I show that, in post-fascist Spain, the impact of exhumations has little to do with their ability to extract historical information directly from the bones of the exhumed. Instead, I argue that exhumations transform the disappeared into dead persons, thereby reincorporating them as integral participants in a democratic public sphere. For memory activists, the project of securing Spain's democratic future depends on recognizing the personhood of long-excluded victims of fascist violence. Absent any official legal framework, I show how Spanish activists train laypersons to recognize the inherent dignity of the dead and see them as potential participants in an alternative democratic public. [Spain; democracy; forensic exhumations; publics; death; forced disappearances; personhood]

\section{RESUMEN}

Cuatro décadas después de la caída del dictador Francisco Franco, España aún rechaza su responsabilidad legal y moral de localizar a los desaparecidos. Este ensayo examina cómo los activistas españoles transforman el estatus político de las víctimas del franquismo a través de las exhumaciones forenses. Partiendo de representaciones académicas y populares de la ciencia forense, demuestro que el impacto de las exhumaciones en la España posfascista tiene poco que ver con la capacidad de extraer los hechos históricos directamente de los huesos exhumados. En lugar de ello, sostengo que los desaparecidos se transforman en personas muertas a través de las exhumaciones $y$, de esa manera, son reincorporados como participantes integrales en la esfera pública democrática. Para los activistas por la memoria, el proyecto de asegurar el futuro democrático de España depende de que las víctimas de la violencia fascista, excluídas por largo tiempo, sean por fin reconocidas como personas. A falta de marco jurídico, demuestro cómo los activistas españoles entrenan a las personas no expertas a reconocer la dignidad de los muertos y considerarlos como participantes potenciales en una esfera pública democrática y alternativa. [España; democracia; exhumaciones forenses; lo público; muerte; desaparición forzada; la persona]

\section{NOTES}

Acknowledgments My enormous gratitude to Michal Ran-Rubin, the anonymous reviewers, and Chris Nelson for their insightful comments on this essay.

1. The ethics of displaying photos of dead bodies in general, and human remains produced through archaeological encounters in particular, has been the subject of much debate (e.g., Keith, Schwalbe, and Silcock 2006; Fehrenbach and Rodogno 2015). Contemporary Western cultural norms hold that corpses ought to be shielded from public view (Ariès 2008). Consequently, the display of the dead body outside of designated medical or funerary spaces is often assumed to be voyeuristic or transgressive. These ethical dilemmas can be particularly fraught within the discipline of anthropology, given the discipline's contributions to a colonial narco-aesthetics, whether through the conscription of corpses by racist pseudoscience, the display of looted remains and funerary artefacts in museums, or even the display of skeletal artefacts in status-affirming cabinets of curiosity (Kakaliouras 2012). While there exists some disagreement within the memory 
movement over the proper way to display pictures of mass graves that respect the dignity of the dead, Spanish memory activists are united in their desire for images of mass graves to circulate as widely as possible. In part, this has to do with their adoption of internationally circulated forensic aesthetics that take visual displays of dead bodies as a touchstone of truth (see Keenan and Weizman 2012). In the Spanish context, the widespread dissemination of images depicting Franco's victims also functions as a critical corrective to a dictatorship that denied the existence of mass graves and a democracy premised on suppressing public representations of these continuing crimes.

2. For some, exhumations provide support for long-marginalized subalterns (Sanford 2003). For others, it risks reinscribing state power, either by allowing for a too-hasty reassertion of state authority (Wagner 2008, 205) or through an overdetermined framework that naturalizes liberal democracy at the expense of alternative political visions (Clarke 2009; Scott 2014). Regardless of these differences, anthropologists tend to agree that exhumations' political force derives from their ability to legitimize historical narratives.

3. While some have questioned the use of the term disappeared in the Spanish context, due to the historical differences with Latin America's Southern Cone, where the legal concept originated (e.g., Gatti 2014), the United Nations has ruled that, given the Spanish state's ongoing refusal to acknowledge the fate of Franco's victims, these acts meet the legal definition of forced disappearance (Ferrándiz 2010; Rubin 2015a).

4. For several years after the passage of the 2007 Law of Historical Memory, the Spain provided limited funding for civil society exhumations. Though the policy demonstrates the growing political power of the memory movement, this funding covered only a fraction of the associations' budget and did not provide a mechanism for the state to take on legal or logistical responsibility for the missing (Moreno 2006).

5. Due to an approaching thunderstorm, this transcript represents an unusually condensed version of the forensic seminar. I owe a tremendous debt of gratitude to Óscar Rodríguez for rescuing my field notebook, which I had inadvertently left out in the rain, as I scrambled to cover the excavation with tarps.

6. These organizational differences in part reflect the complicated intersection of various liberal philosophical, legal, and Catholic traditions of dignity in both legal and colloquial use of the term within Spain. On the varied traditions of the term dignity, see Michael Rosen (2012).

7. On struggles within Spanish constitutional jurisprudence between defining personhood as incorporeal "spiritual and moral value" and personhood as bound to individual physical bodies, see José Enrique Mora Mateo (2000).

8. Reclamar has both colloquial and legal connotations. As such, this comment can be read as a criticism of the ways post-Franco governments limited the ability of the dead to access both the public sphere and the legal system.

9. There is nothing inherently progressive about this kind of politics. Drew Gilpin Faust (2008) convincingly shows how the refusal to allow proper burials of Confederate war dead following the U.S. Civil War led directly to the commemorative efforts that accompanied the establishment of Jim Crow. On the lasting effects of recruiting the dead to perpetuate racial apartheid in the United States, see Mark Auslander (2011).

10. My concern is not with the agency of the dead (cf. Crossland 2009; Rubin 2015b). Such questions of individual agency — whether for the living or the dead — prove less relevant to the kinds of mass movements and publics I focus on in this essay.

\section{REFERENCES}

Aguilar, Paloma

2002 Memory and Amnesia: The Role of the Spanish Civil War in the Transition to Democracy. Translated by Mark Oakley. New York: Berghahn Books.

Anderson, Benedict

1991 Imagined Communities: Reflections on the Origin and Spread of Nationalism. New York: Verso. 
Andrews, James De Witt

1911 American Law and Procedure. Chicago: LaSalle Extension University.

Araguete, Zahira

2013 "Traces of the Past: Working with Archaeology as Ethnographic Object." In Goldsmiths Anthropology Research Papers, edited by Alison Clark, Frances Pine, and

Arendt, Hannah Massimiliano Mollona, 1-13. London: Goldsmiths College.

1998 The Human Condition. 2nd ed. Chicago: University of Chicago Press.

Ariès, Philippe

2008 The Hour of Our Death: The Classic History of Western Attitudes toward Death over the Last One Thousand Years. Translated by Helen Weaver. 2nd ed. New York: Vintage Books.

Asad, Talal

1993 Genealogies of Religion: Discipline and Reasons of Power in Christianity and Islam. Baltimore, Md.: Johns Hopkins University Press.

Auslander, Mark

2011 The Accidental Slaveowner: Revisiting a Myth of Race and Finding an American Family. Athens: University of Georgia Press.

Baets, Antoon de

2004 "A Declaration of the Responsibilities of Present Generations toward Past Generations." History and Theory 43, no. 4: 130-64. https://doi.org/10.1111/ j.1468-2303.2004.00302.x.

Bevernage, Berber, and Lore Colaert

2014 "History from the Grave? Politics of Time in Spanish Mass Grave Exhumations." Memory Studies 7, no. 4: 440-56. https://doi.org/10.1177/1750698014537669.

Bonilla, Yarimar, and Jonathan Rosa

2015 "\#Ferguson: Digital Protest, Hashtag Ethnography, and the Racial Politics of Social Media in the United States." American Ethnologist 42, no. 1: 4-17. https:// doi.org/10.1111/amet.12112.

Boyd, Carolyn P.

2008 "The Politics of History and Memory in Democratic Spain." ANNALS of the American Academy of Political and Social Science 617, no. 1: 133-48. https://doi.

Cabanellas, Guillermo org/10.1177/0002716207312760.

1998 Diccionario Jurídico Elemental. 13th ed. Buenos Aires: Heliasta.

Centro de Investigaciones Sociológicas (CIS)

2008 "Memorias de la Guerra civil y el franquismo. Estudio 2760." http://www.cis.es/ cis/opencm/ES/2_bancodatos/estudios/ver.jsp?estudio=9220\&cuestionario $=$ $10774 \&$ muestra $=16345$.

Chaskalson, Arthur

2002 "Human Dignity in German Law." In The Concept of Human Dignity in Human Rights Discourse, edited by David Kretzmer and Eckart Klein, 313. The Hague: Kluwer Law International.

Clarke, Kamari Maxine

2009 Fictions of Justice: The International Criminal Court and the Challenge of Legal Pluralism in Sub-Saharan Africa. Cambridge, UK: Cambridge University Press.

Collier, Jane F., Bill Maurer, and Liliana Suarez-Navaz

1995 “Sanctioned Identities: Legal Constructions of Modern Personhood." Identities 2, nos. 1-2: 1-27. https://doi.org/10.1080/1070289X.1997.9962524.

Comaroff, Jean, and John L. Comaroff

1991 Of Revelation and Revolution, Volume 1: Christianity, Colonialism, and Consciousness in South Africa. Chicago: University of Chicago Press.

2016 The Truth about Crime: Sovereignty, Knowledge, Social Order. Chicago: University of Chicago Press. 
Crespo Prieto, Andrés

2008 "Informe de la exhumación de restos humanos realizada en tres fosas comunes en A Fonsagrada (Lugo).” Asociación para la Recuperación de la Memoria Histórica,

Crossland, Zoë Ponderrada, Spain.

2009 "OfCluesand Signs: The Dead Bodyand Its Evidential Traces." American Anthropologist 111, no. 1: 69-80. https://doi.org/10.1111/j.1548-1433.2009.01078.x.

2013 "Evidential Regimes of Forensic Archaeology." Annual Review of Anthropology 42: 121-37. https://doi.org/10.1146/annurev-anthro-092412-155513.

Derrida, Jacques

1992 "Force of Law: The 'Metaphysical Foundation of Authority."' In Deconstruction and the Possibility of Justice, edited by Drucilla Cornell, Michel Rosenfeld, and David Gray Carlson, 3-67. New York: Routledge.

1998 Of Grammatology. Translated by Gayatri Chakravorty Spivak. Baltimore, Md.: John Hopkins University Press.

Dziuban, Zuzanna, ed.

2017 Mapping the "Forensic Turn": Engagements with Materialities of Mass Death in Holocaust Studies and Beyond. Vienna: New Academic Press.

Encarnación, Omar G.

2014 Democracy without Justice in Spain: The Politics of Forgetting. Philadelphia: University of Pennsylvania Press.

Espinosa-Maestre, Francisco

2013 Shoot the Messenger? Spanish Democracy and the Crimes of Francoism: From the Pact of Silence to the Trial of Baltasar Garzon. Brighton, UK: Sussex Academic Press.

Farman, Abou

2013 "Speculative Matter: Secular Bodies, Minds, and Persons." Cultural Anthropology 28, no. 4: 737-59. https://doi.org/10.1111/cuan.12035.

Faust, Drew Gilpin

2008 This Republic of Suffering: Death and the American Civil War. New York: Vintage Books.

Fehrenbach, Heide, and Davide Rodogno

2015 “'A horrific photo of a drowned Syrian child': Humanitarian Photography and NGO Media Strategies in Historical Perspective." International Review of the Red Cross 97, no. 900: 1121-55. https://doi.org/10.1017/S1816383116000369.

Ferrándiz, Francisco

2008 "Cries and Whispers: Exhuming and Narrating Defeat in Spain Today." Journal of Spanish Cultural Studies 9, no. 2: 177-92. https://doi.org/10.1080/ 14636200802283704.

2010 "De las fosas comunes a los derechos humanos: El descubrimiento de las desapariciones forzadas en la España contemporánea." Revista de Antropología Social 19: 161-89. http://hdl.handle.net/10261/33428.

2014 El pasado bajo tierra: Exhumaciones contemporáneas de la Guerra Civil. Barcelona: Anthropos Editorial.

Foucault, Michel

2003 "Society Must Be Defended": Lectures at the Collège de France, 1975-1976. New York: Picador.

Gatti, Gabriel

2014 Surviving Forced Disappearance in Argentina and Uruguay: Identity and Meaning. New York: Palgrave Macmillan.

Gessat-Anstett, Élisabeth, and Jean-Marc Dreyfus, eds.

2015 Human Remains and Identification: Mass Violence, Genocide, and the "Forensic Turn." Manchester: Manchester University Press.

Greiff, Pablo de

2014 "Report of the Special Rapporteur on the Promotion of Truth, Justice, Reparation and Guarantees of Non-recurrence: Mission to Spain.” A/HRC/27/56/Add.1. 
United Nations Human Rights Council. https://www.refworld.org/docid/ $543 \mathrm{fc} 0 \mathrm{fc} 4 . \mathrm{html}$.

Hristova, Marije

2007 "Memoria, olvido y la apertura de fosas comunes de la Guerra Civil en 1978-1981 Humphrey, Michael y 2000-2006." Master's thesis, Universidad de Groninga.

2012 “Truth (Truth Seeking and Telling).” In Encyclopedia of Transitional Justice, edited by Lavinia Stan and Nadya Nedelsky, 259-72. Cambridge, UK: Cambridge

Jasanoff, Sheila University Press.

1997 Science at the Bar: Law, Science, and Technology in America. Cambridge, Mass.: Harvard University Press.

Jiménez Campo, Javier

2018 "Artículo 10.1." In Comentarios a la Constitución española, vol. 1, edited by Miguel Rodríguez-Piñero y Bravo Ferrer and María Emilia Casas Baamonde, 213-29. Madrid: Boletín Oficial del Estado.

Joyce, Patrick

2003 The Rule of Freedom: Liberalism and the Modern City. London: Verso.

Kakaliouras, Ann M.

2012 "An Anthropology of Repatriation: Contemporary Physical Anthropological and Native American Ontologies of Practice." Current Anthropology 53, no. S5: S210 21. https://doi.org/10.1086/662331.

Keenan, Thomas, and Eyal Weizman

2012 Mengele's Skull: The Advent of a Forensic Aesthetics. Berlin: Sternberg Press.

Keith, Susan, Carol B. Schwalbe, and B. William Silcock

2006 "Images in Ethics Codes in an Era of Violence and Tragedy." Journal of Mass Media Ethics 21, no. 4: 245-64. https://doi.org/10.1207/s15327728jmme2104_3.

Kirsch, Stuart

2014 "Imagining Corporate Personhood." PoLAR: Political and Legal Anthropology Review 37, no. 2: 207-17. https://doi.org/10.1111/plar.12070.

Leivas, Lidia Mateo, and Zoé de Kerangat

2018 "The Limits of Remembrance during the Spanish Transition: Questioning the 'Pact of Oblivion' through the Analysis of a Censored Film and a Mass-Grave

Locke, John Exhumation." Memory Studies. https://doi.org/10.1177/1750698018777019.

1998 An Essay Concerning Human Understanding. London: Penguin Classics.

Lomnitz, Claudio

2005 Death and the Idea of Mexico. New York: Zone Books.

MacIntyre, Alasdair

2001 Dependent Rational Animals: Why Human Beings Need the Virtues. Revised edition.

Marías, Julián Chicago: Open Court.

1996 Persona. Madrid: Alianza Editorial.

Márquez, Lydia Vicente, and Mercedes Melón

2012 “A European Court of Human Rights' Decision Devoid of Justice." IJCentral, December 12. https://www.foroporlamemoria.info/2012/12/a-european-court-

Mbembe, Achille of-human-rights-decision-devoid-of-justice/.

2003 “Necropolitics." Translated by Libby Meintjes. Public Culture 15, no. 1: 11-40. Moon, Claire https://muse.jhu.edu/article/39984.

2009 Narrating Political Reconciliation: South Africa's Truth and Reconciliation Commission. Lanham, Md.: Lexington Books. 
2017 "Human Rights, Human Remains: Forensic Humanitarianism and the Human Rights of the Dead.” International Social Science Journal 65, nos. 215-216: 49-63. https://doi.org/10.1111/issj.12071.

Mora Mateo, José Enrique

2000 "La dignidad de la persona humana en la jurisprudencia constitucional Española." Cuadernos de bioética 11, no. 42: 257-72.

Moreno, José Antonio

2006 "La memoria defraudada: Notas sobre el denominado proyecto de Ley de Memoria." Hispania Nova 6. http://hispanianova.rediris.es/6/dossier.htm.

Mulgan, Tim

1999 "The Place of the Dead in Liberal Political Philosophy." Journal of Political Philosophy 7, no. 1: 52-70. https://doi.org/10.1111/1467-9760.00065.

Pascual Medrano, Amelia

2015 "La dignidad humana como principio jurídico del ordanamiento Constitucional español." In Dignidad humana y eerecho fundamental, edited by Ricardo Chueca, 295-333. Madrid: Centro de Edtudios Políticos y Constitucionales.

Pateman, Carole

1988 The Sexual Contract. Stanford, Calif.: Stanford University Press.

Patterson, Orlando

2018 Slavery and Social Death: A Comparative Study. Cambridge, Mass.: Harvard University Press.

Pearlman, Adam R.

2008 "Digging for Truth, Justice, or the Humanitarian Way: Priorities in Post-Genocide Transitional Justice and Exhumations of Mass Graves." http://dx.doi.org/10.2139/ ssrn. 1322155 .

Preston, Paul

2012 The Spanish Holocaust: Inquisition and Extermination in Twentieth-Century Spain. London: Harper.

Rancière, Jacques

2010 Dissensus: On Politics and Aesthetics. New York: Continuum.

2013 The Politics of Aesthetics: The Distribution of the Sensible. Edited and translated by Gabriel Rockhill. London: Bloomsbury.

Renshaw, Layla

2011 Exhuming Loss: Memory, Materiality and Mass Graves of the Spanish Civil War. Walnut Creek, Calif.: Left Coast Press.

Robben, Antonius C.G.M.

2000 "The Assault on Basic Trust: Disappearance, Protest, and Reburial in Argentina." In Cultures under Siege: Collective Violence and Trauma, edited by Antonius C.G.M. Robben and Marcelo M. Suárez-Orozco, 70-101. Cambridge, UK: Cambridge

Rosen, Michael University Press.

2012 Dignity: Its History and Meaning. Cambridge, Mass.: Harvard University Press. Rosenblatt, Adam

Rubin, Jonah S.

2015 Digging the Disappeared: Forensic Science after Atrocity. Stanford, Calif.: Stanford University Press.

2014 "Transitional Justice against the State: Lessons from Spanish Civil Society-Led Forensic Exhumations." International Journal of Transitional Justice 8, no. 1: 99-120. https://doi.org/10.1093/ijtj/ijt033.

2015a "Aproximación al concepto de desaparecido: Reflexiones sobre El Salvador y España." Alteridades 25, no. 49: 9-24. https://alteridades.izt.uam.mx/index.php/ Alte/article/view/782/1099.

2015b "Technologies of the Afterlife: The Agency of the Dead at Spanish Mass Grave Exhumations." Anthropological Journal of European Cultures 24, no. 1: 141-49. https://doi.org/10.3167/ajec.2015.240111. 
2018 "How Francisco Franco Governs from beyond the Grave: An Infrastructural Approach to Memory Politics in Contemporary Spain.” American Ethnologist 45, no. 2: 214-27. https://doi.org/10.1111/amet.12633.

Ruiz, Julius

2005 Franco's Justice: Repression in Madrid after the Spanish Civil War. Oxford: Oxford University Press.

Sánchez Gómez, Gonzalo

2016 "Memory Is Essential to Illuminate and Transform." International Center for Transitional Justice, May 24. https://www.ictj.org/debate/article/memory-

Sanford, Victoria essential-illuminate-and-transform.

2003 Buried Secrets: Truth and Human Rights in Guatemala. New York: Palgrave Macmillan. Schachter, Oscar

1983 "Human Dignity as a Normative Concept." American Journal of International Law 77, no. 4: 848-54. https://doi.org/10.2307/2202536.

Scheper-Hughes, Nancy, and Margaret M. Lock

1987 "The Mindful Body: A Prolegomenon to Future Work in Medical Anthropology." Medical Anthropology Quarterly 1, no. 1: 6-41. https://doi.org/10.1525/maq.1987. 1.1.02a00020.

Schmitt, Stefan

2001 "Mass Graves and the Collection of Forensic Evidence: Genocide, War Crimes, and Crimes against Humanity." In Advances in Forensic Taphonomy: Method, Theory, and Archaeological Perspectives, edited by William D. Haglund and Marcella H. Sorg, 277-92. Boca Raton, Fla.: CRC.

Schneider, Kevin

2015 "Judge Recognizes Two Chimpanzees as Legal Persons, Grants Them Writ of Habeas Corpus." Nonhuman Rights Blog, April 20. http://www.nonhumanrightsproject. org/2015/04/20/judge-recognizes-two-chimpanzees-as-legal-persons-grants-

Scott, David them-writ-of-habeas-corpus/.

2014 Omens of Adversity: Tragedy, Time, Memory, Justice. Durham, N.C.: Duke University Press.

Silva, Emilio, and Santiago Macías

2005 Las fosas de Franco: Crónica de un desagravio. Barcelona: Temas de Hoy.

Steadman, Dawnie Wolfe

2003 Hard Evidence: Case Studies in Forensic Anthropology. Upper Saddle River, N.J.: Prentice Hall.

Taussig, Michael

1993 Mimesis and Alterity: A Particular History of the Senses. New York: Routledge.

1999 Defacement: Public Secrecy and the Labor of the Negative. Stanford, Calif.: Stanford

Verdery, Katherine University Press.

1999 The Political Lives of Dead Bodies: Reburial and Postsocialist Change. New York: Columbia University Press.

Wagner, Sarah E.

2008 To Know Where He Lies: DNA Technology and the Search for Srebrenica's Missing.

Warner, Michael Berkeley, Calif.: University of California Press.

2005 Publics and Counterpublics. New York: Zone Books.

Weber, Max

1946 "Science as a Vocation." In From Max Weber: Essays in Sociology, edited by Hans H. Gerth and C. Wright Mills, 129-56. New York: Oxford University Press.

Zigon, Jarrett

2018 Disappointment: Toward a Critical Hermeneutics of Worldbuilding. New York: Fordham University Press. 